\title{
Involvement of Technical Assistants for Teaching Primary Electronic Gadgets uses to Rural People
}

\author{
S. Janifar vinnarasi, R.Vasuki, G. Anandhi
}

\begin{abstract}
The vicious cycle of poverty deprives women, the opportunities to have equal access to participate in many developmental programmes. Self Help Groups has been the most potent gross-roots movement in modern India. The Government recognized the necessity of the empowerment of women by involving them in the economic activity with the use of various voluntary organizations. One such voluntary Non-Government organization is Daughters of Mary Immaculate (DMI) a registered NGO promoted under the MahilarThittam scheme (Mathi) in Kanchipuram District. This study attempts to bring a real picture of Economic impact of women SHG's in Kanchipuram District.
\end{abstract}

Keywords: Self Help Groups, Empowerment, Economic Impact, MahilarThittam

\section{INTRODUCTION}

Women have not been treated on par with men in every aspect of life though their role is crucial for the substance of family, society as well as for the development of economy as a whole. So, women have to empower to make them literates and make themselves free from economic exploitation and oppression[1]-[3]. The creation of employment opportunities for women has always been an important objective of various development programmes. Even though there are many schemes for development of women, Self Help Group for women is one of the successful scheme, which is improving women empowerment and plays a major role to eradicate the poverty particularly in rural areas. SathyaSundaram states that self improvement gatherings are willful relationship of individuals framed to achieve a few objectives. These are bunches that have comparative social character, legacy, position or conventional occupations and meet up for a typical reason and oversee assets to serve the gathering individuals. MahalirThittam (Mathi) is a financial strengthening program for ladies executed by Tamil Nadu Corporation for Development of ladies Ltd. Mathi depends on SHG approach and is actualized in association with N.G.O's. and network based association[4]-[5]. This methodology was begun in a little route in Dharmapuri

Revised Manuscript Received on December 11, 2019

S. Janifar vinnarasi, Department of Science and Humanities, Bharath Institute of Higher Education and Research, Chennai, India. Email: mjjaa24@gmail.com

R. Vasuki, Department of Science and Humanities, Bharath Institute of Higher Education and Research, Chennai , India. Email: vasukiteacher@gmail.com

G. Anandhi, Department of Science and Humanities, Bharath Institute of Higher Education and Research, Chennai , India. Email: anandhi5679@gmail.com
District in the year 1989 and was continuously presented in every one of the locale of the state. Today the SHG development is a dynamic development spread over all locale of the state[21]-[23]. The different strengthening influences a lady overcomes Self Help Groups makes her sure to confront the life and its issues.

The ladies members by joining self improvement gatherings got presentation to casual learning, chance to move with comparative premium partners which gives conscientization and small scale credit, an approach to procure. The womanhood gets an open door for strengthening through these three crucial elements of self improvement gathering[24]-[25]. This strengthening clear them a path for their political, social, prudent and legitimate life which empowers a general underscored employments [6]-[8].

\section{REVIEW OF LITERATURE}

Reinhard Dirk (2006) opines that Micro insurance offers poor people protection from risks, such as destitution caused by illness. He narrates various micro insurance models, the partner asset mode, co-operative model, community model etc., through which there are specific challenges case studies of various models have shown that they can be overcome[9]-[11].

Dr. Jeremy Shapiro et al. (2010) states that Micro finance movement leads to make, financial products and services available to low income households. This will allow house hold to accumulate savings, finance productive endeavors, to manage risks and cash flow.

\section{A. Objective}

To dissect the statistic status of ladies Self Help Groups of DMI in Kanchipuram District and to look at the connection between statistic profiles and monetary effect of ladies in Self Help Groups of DMI in Kanchipuram District.

\section{B. Hypothesis}

The study is based on the following null hypothesis: -

There is no significant relationship between age of the members and the economic impact of DMI in Kanchipuram District[12].

There is no significant relationship between educational qualification of the 
members and the economic impact of DMI in Kanchipuram District.

There is no significant relationship between income level of the members and the economic impact of DMI in Kanchipuram District.

\section{RESULTS AND DISCUSSION}

The Table shows that $35 \%$ of sample respondents are of below 25 years of age and only $4.17 \%$ of sample respondents are more than 40 years. This shows that young women constitutes more in number than the adult women in joining SHG in the study area. This is evident very clearly as more than $83 \%$ of the respondents belongs to less than 35 years of age[13]-[16].

Table 1 : Demographic Profile - Age of the Respondents

\begin{tabular}{|l|l|l|l|}
\hline $\begin{array}{l}\text { Demographic } \\
\text { variables }\end{array}$ & Categories & $\begin{array}{l}\text { No. of } \\
\text { respondents }\end{array}$ & Percentage \\
\hline Age & Up to 25 & 42 & 35.00 \\
\hline & $26-30$ & 33 & 27.50 \\
\hline & $31-35$ & 25 & 20.83 \\
\hline & $36-40$ & 10 & 8.33 \\
\hline & $41-45$ & 5 & 4.17 \\
\hline
\end{tabular}

Table shows that more than $37.5 \%$ of sample respondents who have joined self

help groups are illiterate. This is followed by those who have completed primary education and Secondary Education with $20.83 \%$ and $25 \%$, respectively. From this it can be states those women who are below Secondary level education or illiterate are more interested in joining self help groups as they provide a mean to earn income for their economic upliftment[17]-[19].

Table 2: Demographic profile - educational status of the respondents

\begin{tabular}{|l|l|l|l|}
\hline $\begin{array}{l}\text { Demographic } \\
\text { variables }\end{array}$ & Categories & No. of respondents & Percentage \\
\hline Educational status & Illiterate & 45 & 37.50 \\
\hline & Primary & 25 & 20.83 \\
\hline & S.S.L.C. & 30 & 25.00 \\
\hline & H.Sc & 15 & 12.50 \\
\hline & Degree and above & 5 & 4.17 \\
\hline
\end{tabular}

Table reveals that $41 \%$ of sample respondents who have joined in SHG belongs to category of earning less that Rs. 1,000 per month. $90 \%$ of women who have joined SHG belong to a family whose income are less than Rs. 3000. This shows that lower income female members are more interested to join SHG as they provide alternative employment opportunities to enhance their family income[20].
Table 3: Demographic profile -monthly income of the respondents

\begin{tabular}{|l|l|l|l|}
\hline $\begin{array}{l}\text { Demographic } \\
\text { variables }\end{array}$ & Categories & No. of respondents & Percentage \\
\hline $\begin{array}{l}\text { Monthly family } \\
\text { income (Rs) }\end{array}$ & Less than 1000 & 50352573 & 41.6 \\
\hline & $1001-2000$ & 35 & 29.16 \\
\hline & $2001-3000$ & 25 & 20.83 \\
\hline & $3001-4000$ & 7 & 5.83 \\
\hline & Above 4000 & 3 & 2.50 \\
\hline
\end{tabular}

\section{CONCLUSION}

Financial advancement is the fundamental part of one's improvement. The SHGs help the individuals to improve their financial conditions. The improvement in financial conditions is seen through increment in investment funds, Value of benefits, measure of use, ascend in pay and arrangement of work openings. The impression of the example individuals on the financial effect of Self-Help Groups has been found out by considering different monetary factors. From the measurable examination it is unmistakably indicated that the connection between the statistic factors age and family pay with the financial effect are critical at $5 \%$ level. The statistic variable instruction capability doesn't give measurably huge association with the financial effect. In this manner ladies of youthful age gathering (under 35) having a place with lower family pay gathering are monetarily engaged by the Self Help Groups of DMI in Kanchipuram District of Tamil Nadu.

\section{REFERENCES}

1) Vasanthi, S. \& Rabiyathul Basariya, S. 2019, "Influence of value analysis and cross training in industry", International Journal of Engineering and Advanced Technology, vol. 8, no. 6, pp. 1810-1811.

2) Velvizhi, R., Sri Gowtham, S. \& Jeya Priya, D. 2019, "Examination of early feedbacks for effective product retailing on E-commerce websites", International Journal of Engineering and Advanced Technology, vol. 8, no. 6 Special Issue 2, pp. 703-706.

3) Anuradha, C., Pothumani, S. \& Kavitha, R. 2019, "A novel method towards E-commerce", International Journal of Engineering and Advanced Technology, vol. 8, no. 6 Special Issue 2, pp. 535-538.

4) Thomas, J. \& Rabiyathul Basariya, S. 2019, "A study on the issues of financial ratio analysis", Indian Journal of Public Health Research and Development, vol. 10, no. 3, pp. 1079-1081.

5) Ramachandran, S. \& Rabiyathul Basariya, S. 2019, "Online marketing study on customer satisfaction and relationship", Indian Journal of Public Health Research and Development, vol. 10, no. 3, pp. 1072-1078.

6) Priya, R., Vinothini, G. \& Cor Jesu, C.D. 2019, "The mentor-protégé relationship for professional growth", Journal of Advanced Research in Dynamical and Control Systems, vol. 11, no. 9 Special Issue, pp. 1110-1119.

7) Jannifer Rani, N., Bina Pani, S. \& Nimisha, N.S. 2019, "A study on money back polices available in LIC", Journal of Advanced Research in Dynamical and Control Systems, vol. 11, no. 9 Special Issue, pp. 833-839.

8) Saillaja, V., Jhansi Rani, K. \& Catherine, R. 2019, "Global marketing management planning and organization", Journal of Advanced Research in Dynamical and Control Systems, vol. 11, no. 9 Special Issue, pp. 489-493.

9) Saillaja, V., Jhansi Rani, K. \& Catherine, R. 2019, "The new phase of marketing information system", Journal of Advanced Research in Dynamical and Control Systems, vol. 11, no. 9 Special Issue, pp. $482-488$.

10) Thoufiqulla \& Raju, D.V. 2019, "Perception of indian investor towards investment in mutual funds with special reference to mip funds", Journal of Advanced Research in Dynamical and Control Systems, vol. 11, no. 5, pp. 177-183. 
11) Jasmine, K.R.M. \& Basariya, S.R. 2018, "A study on the customers benefits on mutual funds", International Journal of Civil Engineering and Technology, vol. 9, no. 4, pp. 45-48.

12) Vasanthi, S. \& Basariya, S.R. 2019, "Pros and cons of on the job training versus off the job training", International Journal of Scientific and Technology Research, vol. 8, no. 10, pp. 671-674.

13) Pavithra, J. \& Ganesan, M. 2016, "A study on awareness and impact of micro-financial schemes", International Journal of Applied Business and Economic Research, vol. 14, no. 8, pp. 5449-5460.

14) Pavithra, J., Dilli Babu, P. \& Ambuli, T.V. 2014, "A study on budgetary control at Maruti Service Masters, Chennai", International Journal of Applied Business and Economic Research, vol. 12, no. 2, pp. 151-161.

15) Gunaraja, T.M. \& Venkatrama Raju, D. 2018, "Determining factors of organisational climate with reference to leadership styles", International Journal of Mechanical Engineering and Technology, vol. 9, no. 9, pp. 1327-1332.

16) Gunaraja, T.M. \& Venkatrama Raju, D. 2018, "The role of job satisfaction and training of employees in determining organisational climate of a selected industry", International Journal of Civil Engineering and Technology, vol. 9, no. 8, pp. 1266-1269.

17) Aarathy, T.S. \& Raju, D.V. 2018, "Performance appraisal and its effects on employees with respect to it sector in Chennai city", International Journal of Civil Engineering and Technology, vol. 9, no. 6, pp 1535-1538.

18) Aarathy, T.S. \& Raju, D.V. 2018, "Employee perception towards performance appraisal system in IT sector", International Journal of Mechanical Engineering and Technology, vol. 9, no. 5, pp. 131-135.

19) Porselvi, W., Jublee, D. \& Sivanesan, G. 2018, "A study on factors influencing adoption of technology and innovation in banking industry, tamilnadu, India", International Journal of Mechanical Engineering and Technology, vol. 9, no. 5, pp. 789-800.

20) Akessa, G.M. and Dhufera, A.G., 2015. Factors That Influences Students Academic Performance: A Case of Rift Valley University, Jimma, Ethiopia. Journal of Education and Practice, 6(22), pp.55-63.

21) Miller, G. and Shih, C.C., 1999. A faculty assessment of the academic rigor of on-and off-campus courses in agriculture. Journal of Agricultural Education, 40, pp.57-65.

22) Tsinidou, M., Gerogiannis, V. and Fitsilis, P., 2010. Evaluation of the factors that determine quality in higher education: an empirical study. Quality Assurance in education, 18(3), pp.227-244.

23) Farooq, M.S., Chaudhry, A.H., Shafiq, M. and Berhanu, G., 2011. Factors affecting students' quality of academic performance: a case of secondary school level. Journal of quality and technology management, 7(2), pp.1-14

24) Fitsilis, P., Gerogiannis, V. and Anthopoulos, L., 2014. Ontologies for software project management: a review. Journal of Software Engineering and Applications, 7(13), p.1096.

25) Adams, J.D. and Jaffe, A.B., 1996. Bounding the effects of R\&D: an investigation using matched establishment-firm data(No. w5544). National bureau of economic research.

\section{AUTHORS PROFILE}

S. Janifar vinnarasi Assistant Professor, Department of Science and Humanities, Bharath Institute of Higher Education and Research, Chennai, India.

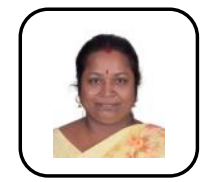

R. Vasuki Assistant Professor, Department of Science and Humanities, Bharath Institute of Higher Education and Research, Chennai, India.

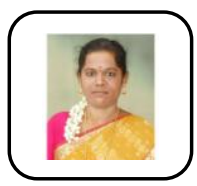

G. Anandhi Assistant Professor, Department of Science and Humanities, Bharath Institute of Higher Education and Research, Chennai, India. 